\title{
PREDICTORS OF ENTREPRENEURIAL INTENTIONS OF STUDENTS OF ECONOMICS
}

\author{
Ana JAKOPEC ${ }^{1}$, Irena MILJKOVIĆ KREČAR, Zoran SUŠANJ \\ ${ }^{1}$ Faculty of Humanities and Social Sciences in Osijek \\ L. Jägera 9, 31000 Osijek, Croatia \\ E-mail: ajakopec1@ffos.hr
}

\begin{abstract}
The aim of this empirical research is to verify the contribution of entrepreneurial tendencies and abilities, perceived entrepreneurial self-efficacy and desirability of entrepreneurship to the entrepreneurial intentions. This model was generated according to the framework of the Theory of planned behavior and Model of the entrepreneurial event. Data was collected from a sample of undergraduate students of economics and analyzed with SEM. The results show that the self-assessment of entrepreneurial tendencies and abilities is positively associated with the perceptions of entrepreneurial self-efficacy and desirability of entrepreneurship, which also contributes positively to explanation of entrepreneurial intentions. In addition, it was found that entrepreneurial tendencies and abilities influence entrepreneurial intentions only indirectly, through entrepreneurial self-efficacy and desirability of entrepreneurship. Finally, entrepreneurial tendencies and abilities, entrepreneurial self-efficacy and desirability of entrepreneurship together, explain most of the variance of the entrepreneurial intentions. Educational implications of obtained results are being discussed.
\end{abstract}

Key words: entrepreneurial tendencies and abilities, entrepreneurial self-efficacy, desirability of entrepreneurship, entrepreneurial intentions

\section{THEORETICAL FRAMEWORK AND HYPOTHESIS DEVELOPMENT}

Entrepreneurship is described as the process of organizational emergence (Gartner et al., 1992). Entrepreneurial intentions, described as the conscious state of mind that affects and directs personal attention, events, and behavior toward planned entrepreneurial behavior (Bird, 1988), are essential to this process, shaping the primal in a chain of actions to organizational founding. Moreover, intentions toward behavior can be strong indicators of that behavior (Fishbein, Ajzen, 1975).

Studies had shown that entrepreneurial intentions and behavior can be influenced through education (Fayolle et al., 2006; Tkachev, Kolvereid, 1999). University is an institution which students go through on their way toward their business life. University students will be engaged in career decisions imminently after, and often before, graduation. In our opinion, students tend to gravitate toward popular career options.

Given that entrepreneurial behavior is, among other factors, also a function of individual differences, (Kuratko, 2007; McKenzie, Ugbah, Smothers, 2007) personality and ability factors should predict entrepreneurial activity and success (Rauch, Frese, 2007; Zhao, Seibert, 2006). There are various constructs that may predict individual differences in entrepreneurship. Recent studies are still trying to generate a com-

DOI: $10.21909 /$ sp.2013.04.643 
prehensive measure of entrepreneurial characteristics in terms of entrepreneurial tendencies and abilities, thereby combining the factors already identified in new combinations and models. Caird (1988) finds a combination of factors: motive for achievement and independence, drive and determination, risk-taking and creativity, all discriminative for entrepreneurial propensity forming. Miljković Krečar (2010) defines the entrepreneurial propensity factors as confidence in one's own capabilities, risk acceptance and unconventionality and focus on the achievement. Ahmetoglu and Chamorro-Premuzic (2010) found entrepreneurial awareness, need for progress, opportunism and entrepreneurial creativity to be a strong predictor combination of entrepreneurial activity.

Two models guide our understanding of entrepreneurial intentions: Ajzen's (1991) Theory of Planned Behavior (TPB), and Shapero and Sokol's (1982) Model of the Entrepreneurial Event (EEM). The TPB is designed to predict and explain human behavior. This theory postulates that attitudes, social norms, and perceived control are the immediate predictors of behavioral intentions. TheEEM model focuses on how the social and cultural environment affects the choice of an entrepreneurial path. This model was developed to understand entrepreneurial behavior. Entrepreneurial intentions originate from perceptions of desirability, feasibility (i.e., selfefficacy), and a tendency to perform upon opportunities. In this model, Shapero and Sokol (1982) define perceived desirability as the degree to which one finds the possibility of starting a business to be attractive and perceived feasibility as the extent to which a person feels competent to do so.

Both the TPB and EEM models provide comparable interpretations of entrepreneur- ial intentions (Krueger, 1993; Krueger et al., 2000). Krueger et al. (2000) explained that 1) attitudes and biased norms in the TPB model are conceptually linked to perceived desirability in EEM and that 2) perceived behavioral control in TPB matches perceived feasibility in the EEM model. Basically, perceived desirability and perceived feasibility are essential elements of intentional behavior.

According to the TPB, attitude toward the behavior refers to the extent to which a person has a favorable or unfavorable evaluation of that behavior. Social norms refer to the perceived social pressure to engage or not to engage in that behavior. They are linked to our perceptions of what referent others would think about our entrepreneurial intentions. The TPB involves also the antecedents of attitudes toward the behavior and subjective norms. It postulates that behavior is a function of beliefs relevant to the intended behavior. These beliefs are deemed to be the prevalent determinants of a person's attitudes, intentions and behavior (Ajzen, 1991). Behavioral beliefs are assumed to inuence attitudes toward the behavior. Each belief links the behavior to a certain outcome, which is already valued positively or negatively. Therefore, people automatically acquire an attitude toward the behavior. That is the way that people form favorable attitudes toward behaviors believed to have desirable consequences, and negative attitudes toward behaviors associated with undesirable consequences (Ajzen, 1991). Subjective normative beliefs constitute their underlying determinants. They relate to the possibility that important referent individuals or groups approve or disapprove of performing a given behavior (Ajzen, 1991). 
On the other hand, Shapero and Sokol (1982) examine the concept of desirability using data on the family, peer groups, ethnic groups, professional and educational contexts of potential entrepreneurs. In the case of the family, they state that parents play the most powerful role in establishing the desirability of the entrepreneurial behavior. Also, the larger number and a greater variety of entrepreneurs in a society will also lead to the greater probability that the individuals in that culture or society will engage in venture startup (Veciana et al., 2005).

Perceived behavioral control plays an important role in the TPB and it is dened as the individual's perception of the ease or difculty of performing the behavior (Ajzen, 1991). The resources and opportunities attainable by a person must to some extent dictate the possibility of behavioral fulfillment. The antecedents of perceived behavioral control are the control beliefs. These beliefs deal with the presence or absence of requisite resources and opportunities. They may be based on past experiences, second hand information about that behavior, the experiences of colleagues and friends, and also on other factors that increase or reduce the perceived difficulty of performing the intended behavior (Ajzen, 1991). Related to the perceived feasibility, EEM emphasizes the perception of the availability of financial, advice, consultation and education support that make the act of entrepreneurial behavior feasible to the potential entrepreneur (Shapero, Sokol, 1982).

Therefore, the aim of this empirical research is to verify the contribution of entrepreneurial tendencies and abilities (entrepreneurial potential), perceived entrepreneurial selfefficacy and desirability of entrepreneurship to the entrepreneurial intentions.
$H 1$ : Entrepreneurial potential is positively linked and has both, direct and indirect effects on entrepreneurial intentions.

H2: Entrepreneurial potential is positively linked to entrepreneurial self-efficacy.

H3: Entrepreneurial potential is positively linked to the desirability of entrepreneurship.

H4: Entrepreneurial self-efficacy is positively linked to entrepreneurial intentions.

H5: Desirability of entrepreneurship is positively linked to entrepreneurial intentions.

H6: Perceived entrepreneurial self-efficacy and desirability of entrepreneurship mediate the relationship between entrepreneurial potential and entrepreneurial intentions.

\section{METHOD}

\section{Participants and Procedure}

Data was collected from a convenient sample of 315 undergraduate students of economic fields (Faculty of Economics in Rijeka $(\mathrm{N}=142)$, Faculty of Economics in Osijek ( $\mathrm{N}=129)$ and VERN' University of Applied Sciences in Zagreb $(\mathrm{N}=44))$. The gender composition of the sample was $77.5 \%$ female and $22.5 \%$ male. The research was conducted in larger or smaller groups on the students' faculties, and it lasted approximately 25 minutes. Participation in the survey was anonymous and voluntary.

\section{Instruments}

Measure of Entrepreneurial Tendencies and Abilities (META L61, adjusted from Ahmetoglu, Chamorro-Premuzic, 2010) was used as the measure of entrepreneurial potential. This scale contains 61 items measuring 4 different aspects of entrepreneurial 
personality: entrepreneurial awareness (11 items), entrepreneurial creativity (12), opportunism (18) and need for progress (20). Items were presented in Likert-type format with a scale extending from 1 (strongly disagree) to 5 (completely agree). Composite score was calculated by summing across items, with higher scores indicating higher entrepreneurial potential. Cronbach's alpha coefficients for the four dimensions of entrepreneurial potential were .92 for entrepreneurial awareness, .97 for entrepreneurial creativity, .95 for opportunism and .93 for need for progress. Cronbach's alpha coefficient for the overall entrepreneurial potential was .96 .

Entrepreneurial self-efficacy scale (adjusted from Liñàn, Chen, 2006) was used to assess entrepreneurial self-efficacy. The scale contains 6 items, presented in Likerttype format with a scale extending from 1 (strongly disagree) to 5 (completely agree). Composite score was calculated by summing across items, with higher scores indicating higher entrepreneurial self-efficacy. Cronbach's alpha coefficient was .79.

Desirability of Entrepreneurship Scale (adjusted from Liñàn, Chen, 2006) was used to assess the desirability of entrepreneurship. The scale contains 5 items presented in Likert-type format with a scale extending from 1 (strongly disagree) to 5 (completely agree). Composite score was calculated by summing across items, with higher scores indicating higher desirability of entrepreneurship. Cronbach's alpha coefficient was .86 .

Entrepreneurial Intentions Questionnaire (adjusted from Liñàn, Chen, 2006) was used to assess entrepreneurial intentions. The scale contains 6 items, presented in Likerttype format with a scale extending from 1 (strongly disagree) to 5 (completely agree). Composite score was calculated by summing across items, with higher scores indicating higher entrepreneurial intentions. Cronbach's alpha coefficient was .90 .

\section{RESULTS}

\section{Descriptive Statistics and Correlations}

Descriptive statistics and correlations of all measured variables are presented in Table 1. As expected, the associations between entrepreneurial potential and both mediating variables were positive $(r=.67$ for entrepreneurial self-efficacy and .44 for desirability of entrepreneurship, $\mathrm{p}<.01$ ), as well as the association between entrepreneurial potential and entrepreneurial intentions $(\mathrm{r}=.51$, $\mathrm{p}<.01$ ). Finally, both mediating variables also generated positive associations with entrepreneurial intentions $(\mathrm{r}=.70$ for entrepreneurial self-efficacy and .80 for desirability of entrepreneurship, $\mathrm{p}<.01$ ).

\section{Structural Equations Modeling}

Structural Equation Modeling (SEM) techniques, which approve researchers to assess how closely a theoretical model matches an existing data set, were used to test the hypothesized model (Figure 1). Generally, a nonsignificant chi-square, Normed-fit index (NFI), Comparative fit index (CFI), Goodnessof-fit statistic (GFI) and Tucker-Lewis index $(T L I) \geq .95$, Adjusted goodness-of-fit statistic $(\mathrm{AGFI}) \geq .95$, Root mean square error of approximation (RMSEA) $<.07$ and Standardized root mean square residual $(\mathrm{SRMR})<.05$ indicate very good model fit (Byrne, 1998; Hu, Bentler, 1999; Miles, Shevlin, 1998; Steiger, 2007; Hooper et al., 2008). 
Table 1. Means, Standard Deviations, Cronbach's alpha coefficients and Correlations of all variables measured

\begin{tabular}{|l|c|c|c|c|c|c|c|c|c|c|}
\hline & \multicolumn{3}{|c|}{ Descriptive Statistics } & \multicolumn{7}{|c|}{ Correlations } \\
\cline { 2 - 12 } & $\mathrm{M}$ & $\mathrm{SD}$ & $\alpha$ & 2 & 3 & 4 & 5 & 6 & 7 & 8 \\
\hline $\begin{array}{l}\text { 1. Entrepreneurial } \\
\text { Awareness }\end{array}$ & 35.66 & 5.57 & .92 & .76 & .57 & .56 & .86 & .65 & .41 & .49 \\
\hline 2. Opportunism & 59.07 & 8.93 & .95 & & .50 & .57 & .87 & .63 & .46 & .52 \\
\hline $\begin{array}{c}\text { 3. Entrepreneurial } \\
\text { Creativity }\end{array}$ & 40.34 & 6.50 & .97 & & & .42 & .73 & .41 & .19 & .21 \\
\hline $\begin{array}{c}\text { 4. Need for } \\
\text { Progress }\end{array}$ & 78.89 & 9.57 & .93 & & & & .81 & .49 & .36 & .40 \\
\hline $\begin{array}{c}\text { 5. Entrepreneurial } \\
\text { Potential }\end{array}$ & 214.33 & 25.07 & .96 & & & & & .67 & .44 & .51 \\
\hline $\begin{array}{c}\text { 6. Entrepreneurial } \\
\text { Self-efficacy }\end{array}$ & 21.41 & 4.13 & .79 & & & & & & .65 & .70 \\
\hline $\begin{array}{c}\text { 7. Desirability of } \\
\text { Entrepreneurship }\end{array}$ & 19.08 & 4.53 & .86 & & & & & & & .80 \\
\hline $\begin{array}{c}\text { 8. Entrepreneurial } \\
\text { Intentions }\end{array}$ & 20.62 & 6.41 & .90 & & & & & & & \\
\hline
\end{tabular}

Note: $\mathrm{N}=315$. Items were rated on a 5-point Likert-type scale. All $r$ s are significant at $\mathrm{p}<.01$

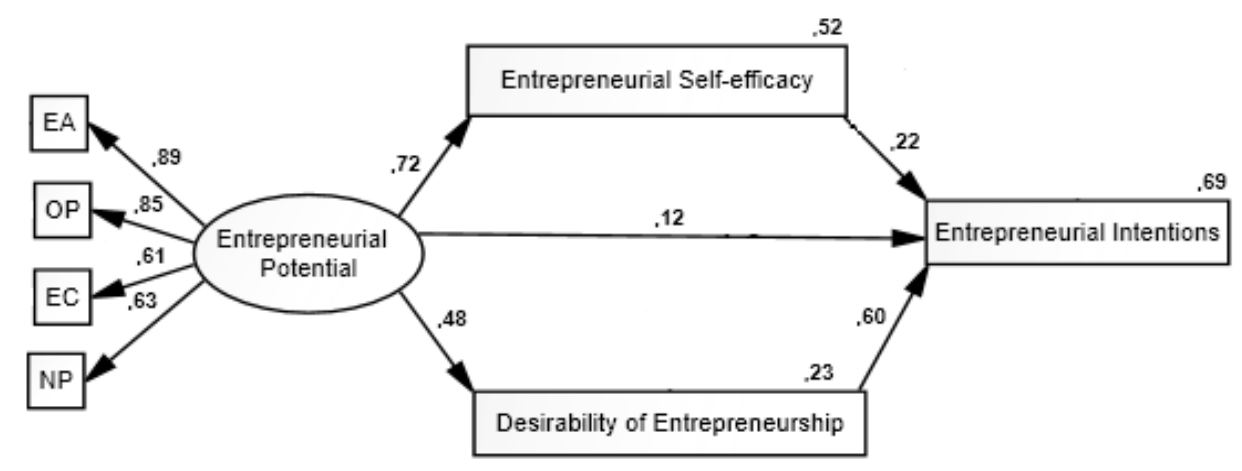

Legend:
EA-Entrepreneurial Awareness
OP - Opportunism
EC-Entrepreneurial Creativity
$\mathrm{NP}$ - Need for Progress

Figure 1. Predictors of entrepreneurial intentions of students of economics 
The results indicated a very good fit by all indices $\left(\chi^{2}[\mathrm{df}=8 ; \mathrm{N}=315]=10.39, \mathrm{p}=\right.$ $.239 ; \mathrm{SRMR}=.019 ; \mathrm{CFI}=.998 ; \mathrm{GFI}=.991$; $\mathrm{AGFI}=.968 ; \mathrm{NFI}=.992 ; \mathrm{TLI}=.995 ; \mathrm{RMSEA}$ $=.031)$.

According to the proposed hypothesis, the (standardized) parameters of the model supported the positive influence of entrepreneurial potential on perceived entrepreneurial self-efficacy $(\beta=.72, \mathrm{p}<.001)$, and desirability of entrepreneurship $(\beta=.48, \mathrm{p}$ $<.001)$. These findings fully support $H 2$ and $H 3$. Perceived entrepreneurial self-efficacy $(\beta=.22, p<.001)$ and desirability of entrepreneurship $(\beta=.60, p<.001)$ positively influenced entrepreneurial intentions, which fully supports $\mathrm{H} 4$ and $H 5$.

We also proposed that perceived entrepreneurial self-efficacy and desirability of entrepreneurship would mediate the relationship between entrepreneurial potential and entrepreneurial intentions. In order to determine the significance of a mediation effect, a Monte-Carlo (bootstrapping) approximation was brought out by creating a bias-corrected percentile method (1000 samples; confidence interval of 90).

It was found that entrepreneurial potential positively influenced entrepreneurial intentions through its relations to perceived entrepreneurial self-efficacy and desirability of entrepreneurship $(\beta=.45, p<.01)$. Entrepreneurial potential had also direct, positive effect on entrepreneurial intentions $(\beta=.12, p<.05)$. These findings support $H 1$ and $H 6$. Entrepreneurial potential, perceived entrepreneurial self-efficacy and desirability of entrepreneurship explained $69 \%$ of entrepreneurial intentions variance. The theoretical and practical implications of these findings are discussed below.

\section{DISCUSSION}

Entrepreneurial potential, defined as a combination of personal characteristics - entrepreneurial awareness, entrepreneurial creativity, opportunism, and need for progress makes significant predisposition for creating entrepreneurial intentions. This effect is achieved also through perception of one's own competencies in entrepreneurship (i.e., entrepreneurial self-efficacy), and through the perception that entrepreneurship is a desirable career option (i.e., desirability of entrepreneurship). Together, these three sources explain $69 \%$ of variance of entrepreneurial intentions. This is a significant finding that additionally confirms the theoretical background of the tested model - Ajzen's (1991) Theory of Planned Behavior, and Shapero and Sokol's (1982) Model of the Entrepreneurial Event. However, main shortage of these findings lies in the fact that the criterion variable was a subjective appraisal of future behavior. That is, we confirmed the significance of predictors of entrepreneurial intentions, however, that does not automatically imply their significance in predicting actual entrepreneurial behavior later in time. For that kind of conclusion, longitudinal studies should be made. However, having in mind that earlier research studies have confirmed intentions as being significant predictors of behavior (Fishbein, Ajzen, 1975), general practical implications of these findings are discussed in the following text.

The impact that academic education may have on entrepreneurial personal characteristics is somewhat debatable. Personal characteristics are formed throughout life, as a result of environmental and genetic interaction. Concrete parent's behaviors that foster 
or inhibit children's skills and knowledge development, together with the parent's level of work values and commitment, influence children's characteristics and later work behavior (O'Brien, Fassinger, 1993). Also, it has been proven that career identity forms under the influence of early school and work related experiences (Feldman, 2002). Therefore, children who grow up in entrepreneurs' families gain advantage in the development of entrepreneurial characteristics and tendencies, this is then manifested in a higher rate of entrepreneurs among entrepreneurs' children (Zellweger et al., 2010). This leads to generally accepted conclusion that education for entrepreneurship should be integrated in the earliest phase of formal education, including kindergartens. Teaching and encouraging children to be more creative, to recognize opportunities, and to take initiative in order to achieve high goals, could influence their later interest in entrepreneurial behavior. School systems should not only be informative concerning entrepreneurship, but should also provide opportunities for testing and developing entrepreneurial characteristics, which would include a lot of practical assignments. Having opportunities for experiencing success in various, typical entrepreneurial activities, could also foster entrepreneurial self-efficacy.

The third way to influence entrepreneurial intent is through influencing the perception of desirability of entrepreneurship and entrepreneurs. In order to achieve that, many legal and administrative steps of starting and running a company should be made. In media, we often hear the argument that having one's own business is complicated, risky and full of ambiguity. Although people will always differ in the level of comfort they experience in ambiguity and risky environments, that is, some part of the population will prefer working for others in any environment, the general perception of easiness of starting one's own company and advantages of entrepreneurship in general could be influenced.

This study has some limitations as well. First, the study design does not allow conclusions about the causal relationship between constructs, it does not determine the process of their development and changes over time, nor does it raise the possibility of alternative interpretations of the results. Second, the variables data were collected from the same sources, at the same time, using the same (self-ratings) method. This brings up the issue of common method variance. With this type of research design, the correlation between measures may be attributed to the same-source data rather than a real underlying relationship (Podsakoff, Organ, 1986). In order to address the issue of common method variance, a Harman's single-factor test (Podsakoff, Organ, 1986) was conducted by performing an exploratory factor analysis on all the variables of the study. Podsakoff et al. (2003) indicated that this single-factor test is a widely used technique for addressing the issue of common method variance. An examination of the unrotated factor structure of the variables was conducted and the single-factor analysis revealed that no single factor accounted for the majority (more than 50\%) of the covariance. The first factor accounted for only $24 \%$ of the variance. A single factor did not emerge from the factor analysis and one general factor did not account for the majority of the covariance among the measures (Podsakoff et al., 2003); therefore, it did not appear that common method variance represented a problem for this study. Third, due 
to prevailing female gender composition of the sample, it is questionable how far the model results are consistent across two gender groups. In order to address this question, additional analysis was performed. Results of multi-group analysis indicated that the model does apply across groups and does display multi-group invariance. Precisely, the basic model structure (same variable parameter pattern), strength of the relationship between constructs (path coefficients) and the amount of constructs (variable intercepts) do not significantly differ across gender groups.

Fostering entrepreneurship is one of the strategic goals of our government as it impacts economic development. Still, in our country, entrepreneurship is mainly (almost exclusively) taught at economic faculties, thereby ignoring the developmental nature of entrepreneurial characteristics and tendencies as the main prerequisites for creating venture. Without entrepreneurs, entrepreneurship does not exist, and entrepreneurs could and should be nurtured as well as educated. Hopefully this research will improve the understanding of the psychological processes that precede a venture startup, and turn the focus from the "dance" to the "dancer".

Received May 7, 2013

\section{REFERENCES}

AHMETOGLU, G., CHAMORRO-PREMUZIC, T., 2010, Measure of entrepreneurial tendencies and abilities. Unpublished Measure (available on request).

AJZEN, I., 1991, The theory of planned behavior. Organizational Behavior and Human Decision Processes, 50, 179-211.

BIRD, B., 1988, Implementing entrepreneurial ideas: The case for intention. Academy of Management Review, 13, 442-453.
BYRNE, B.M., 1998, Structural equation modeling with LISREL, PRELIS and SIMPLIS: Basic concepts, applications and programming. Mahwah/New Jersey: Lawrence Erlbaum Associates.

CAIRD, S., 1988, A review of methods of measuring enterprising attributes. Durham University Business School/Durham: NC.

FAYOLLE, A., GAILLY, B., LASSAS-CLERC, N., 2006, Assessing the impact of entrepreneurship education programmes: A new methodology. Journal of European Industrial Training, 30, 9, 701720 .

FELDMAN, D.C., 2002, Stability in the midst of change: A developmental perspective on the study of careers. In: D.C. Feldman (Ed.), Work Careers. Yossey-Bass/San Francisco.

FISHBEIN, M., AJZEN, I., 1975, Belief, attitude, intention, and behavior: An introduction to theory and research. Addison/Wesley: New York.

GARTNER, W.B., BIRD, B.J., STARR, J.A., 1992, Acting as if: Differentiating entrepreneurial from organizational behavior. Entrepreneurship Theory and Practice, 16, 13-31.

HOOPER, D., COUGHLAN, J., MULLEN, M.R., 2008, Structural equation modelling: Guidelines for determining model fit. Electronic Journal of Business Research Methods, 6, 1, 53-60.

HU, L.T., BENTLER, P.M., 1999, Cutoff criteria for fit indexes in covariance structure analysis: Conventional criteria versus new alternatives. Structural Equation Modeling, 6, 1, 1-55.

KRUEGER, N.F., 1993, The impact of prior entrepreneurial exposure on perceptions of new venture feasibility and desirability. Entrepreneurship Theory and Practice, 18, 1, 5-21.

KRUEGER, N.F., REILLY, M.D., CARSRUD, A.L., 2000, Competing models of entrepreneurial intentions. Journal of Business Venturing, 15, 5/6, 411-432.

KURATKO, D.F., 2007, Entrepreneurial leadership in the 21st century. Journal of Leadership and Organizational Studies, 13, 4, 1-11.

LIÑÁN, F., CHEN,Y., 2006, Testing the entrepreneurial intention model on a two-country sample. Document de Treball Universitat Autňnoma de Barcelona: Departament d'Economia de l'Empresa. http://webs2002.uab.es/dep-economiaempresa/documents/06-7.pdf

MCKENZIE, B., UGBAH, S.D., SMOTHERS, N., 2007, „Who is an entrepreneur?" Is it still the wrong question? Academy of Entrepreneurship Journal, 13, 1, 34-65. 
MILES, J., SHEVLIN, M., 1998, Effects of sample size, model specification and factor loadings on the GFI in confirmatory factor analysis Personality and Individual Differences, 25, 85 90.

MILJKOVIĆ KREČAR, I., 2010, Teorijski modeli poduzetničke karijere. Društvena istraživanja, 3, 107, 441-461.

O'BRIEN, K.M., FASSINGER, R.E., 1993, A causal model of the career orientation and career choice of adolescent women. Journal of Counseling Psychology, 40, 456-469.

PODSAKOFF, P.M., MACKENZIE, S.B., LEE, J.-Y., PODSAKOFF, N.P., 2003, Common method biases in behavioral research: A critical review of the literature and recommended remedies. Journal of Applied Psychology, 88, 879-903.

PODSAKOFF, P.M., ORGAN, D.W., 1986, Selfreports in organizational research: Problems and prospects. Journal of Management, 12, 531-544.

RAUCH, A., FRESE, M., 2007, Let's put the person back into entrepreneurship research: A metaanalysis on the relationship between business owners' personality traits, business creation, and success. European Journal of Work and Organizational Psychology, 16, 4, 353-385.

SHAPERO, A., SOKOL, L., 1982, The social dimensions of entrepreneurship. In: C.A. Kent, D.L.
Sexton, K.H. Vesper (Eds.), Encyclopedia of Entrepreneurship (pp. 72-90). Prentice Hall/Englewood Cliffs: New York.

STEIGER, J.H., 2007, Understanding the limitations of global fit assessment in structural equation modeling. Personality and Individual Differences, 42, 5, 893-98.

TKACHEV, A., KOLVEREID, L., 1999, Self employment intentions among Russian students. Entrepreneurship \& Regional Development, 11, 269-280.

TRICE, A., 1991, Relationship among first aspirations, parental occupations and current occupations. Psychological Reports, 68, 1, 287-290.

VECIANA, J.M., APONTE, M., URBANO, D., 2005, University students' attitudes towards entrepreneurship: A two countries comparison. International Entrepreneurship and Management Journal, 1, 2, 165-182.

ZELlWEGER, T., SIEGER, P., HALTER, F. et al., 2010, Should I stay or should I go? Career choice intentions of students with family business background. Journal of Business Venturing, 26, 521536.

ZHAO, H., SEIBERT, S.E., 2006, The Big Five personality dimensions and entrepreneurial status: A meta-analytical review. Journal of Applied Psychology, 91, 259-271.

\title{
PREDIKTORY PODNIKATELSKÝCH ZÁMEROV U ŠTUDENTOV EKONÓMIE
}

\author{
A. J a k o pec, I. M i lj k ović K r e ča r, Z. S u šanj
}

Súhrn: Ciel'om empirického výskumu bolo overit', ako vplývajú podnikatel'ské sklony a schopnosti, vnímaná podnikatel'ská sebaúčinnost' a žiadúcnost' podnikania na podnikatel'ské zámery. Model bol generovaný na základe Theory of planned behavior (Teórie plánovaného správania) a Model of the entrepreneurial event (Modelu podnikatel'skej udalosti). Výskumnú vzorku tvorili študenti ekonómie a údaje sme analyzovali prostredníctvom SEM. Výsledky ukázali, že sebahodnotenie podnikatel'ských sklonov a schopností má pozitívny vzt'ah s vnímaním podnikatel'skej sebaúčinnosti a žiadúcnosti podnikania, ktorá rovnako pozitívne vysvetl'uje podnikatel'ské zámery. Okrem toho sme zistili, že podnikatel'ské sklony a schopnosti ovplyvňujú podnikatel'ské zámery iba nepriamo, prostredníctvom podnikatel'skej sebaúčinnosti a žiadúcnosti podnikania. Podnikatel'ské sklony a schopnosti, spolu s podnikatel'skou sebaúčinnost'ou a žiadúcnost'ou podnikania vysvetl'ujú väčšinu variancie podnikatel'ských zámerov. Diskutuje sa použitie dosiahnutých výsledkov v procese výučby. 